\title{
VENE KEELE MÕJUST EESTI KEELES. TAGASIVAATEID JA PERSPEKTIIVE ${ }^{1}$
}

\author{
Rogier Blokland \\ Hamburgi Ülikool \\ Petar Kehayov \\ Tartu Ülikool
}

Kokkuvõte. Artiklis uuritakse vene keele mõju eesti keele sõnavarale ja morfosüntaksile; venemõjulise sõnavara käsitluses võetakse kriitiliselt kokku varasemate uurimuste tulemusi, venemõjulise morfosüntaksi käsitluses aga esitatakse rida uusi vene mõju kandidaate eesti keele grammatika erinevates valdkondades. Artiklis väidetakse, et võõrmõjulise morfosüntaksi uuringute „mahajäämuse“ põhjused võrreldes sõnavaraga ei ole niivõrd ideoloogilised, kuivõrd ontoloogilised. Grammatikauuenduste tekkimine ja juurdumine ei saa kunagi olla ainult teise keele mõju tulemus. Seetõttu on väliseid uuenduste ajendeid raske uurida eraldi sisemistest ajenditest. Artiklis jõutakse järelduseni, et vene keele mõju eesti keelele positsioneerub oma ulatuselt Thomasoni ja Kaufmani (1988) laenuskaalal teise ja kolmanda intensiivsusastme vahel.

Märksõnad: keelekontakt, interferents, eesti keel, vene keel, sõnavara, morfosüntaks

\section{Sissejuhatus}

Viimase kahekümne aasta jooksul on eesti ja vene keele staatusvahekord Eestis muutunud ning koos sellega on nihkunud ka eesti kontaktlingvistika fookus. Kui 1980ndatel ja 1990ndate al-

\footnotetext{
${ }^{1}$ Artikli valmimist on toetanud ETFi grandid 7006 ja 7464 . Oleme tänu võlgu Nikolai Kuznetsovile ja Liina Lindströmile, kes toimisid keelejuhtidena ning mõtlesid aktiivselt meiega kaasa.
} 
guses olid tulipunktis vene keele „ohud“ eesti keelele, siis tänapäeval tegeletakse peamiselt eesti mõjudega eestivenelaste emakeeles, sealhulgas uuritakse vene keelel baseeruva vahekeele kujunemist (vt nt Verschik 2008 ja Zabrodskaja 2009). Kandes kahe aastakümne tagust kõnepruuki tänapäeva, võiksime neid moodsaid interferentsiuurimusi taandada küsimusele: millised on eesti keele „ohud“ Eesti vene keelele - küsimus, mis kogu oma spekulatiivsuses kõneleb paradigma täielikust pöördest.

Vaatamata kõikidele muutustele, on keeled jätkuvalt kontaktis, millest kumbki osapool ei pääse täiesti puhtana. Vene keele mõningases mõjus on lihtne veenduda, lugedes näiteks internetifoorumeid, kus tuhanded eestivenelased kirjutavad päris heas eesti keeles, mille kaudu aga aega-ajalt imbub eesti keelde tõlkelaenulisi struktuure. Need struktuurid võivad osutuda atraktiivseteks, seda eriti eesti noorte jaoks, kes vene keelt ei valda ja kelle jaoks on seetõttu nende päritolu läbipaistmatu. Käesoleva artikli eesmärgiks on pakkuda lisamõtlemisainet neile, kes nagu meiegi tahaksid kunagi jõuda selgusele, milline on vene keele mõju tegelik ulatus eesti keeles.

Arutelu koosneb kahest osast: a) vene keele mõju eesti keele sõnavaras ja b) vene keele mõju eesti keele morfosüntaksis. See jaotus on paljuski tinglik: vene mõjust näiteks grammatiliste (suletud klassidesse kuuluvate) sõnade puhul tuleb juttu mõlemas peatükis, olgugi et erinevast vaatenurgast. Lisaks sellele on sõnavara ja morfosüntaksi käsitlused oma sügavuse ja üldistusjõu poolest üsnagi erinevad: see tuleneb esiteks valdkondade üldisest uurituse astmest, teiseks rõhuasetusest. Kui siinne sõnavarakäsitlus on juba olemasoleva eriuurimuse (Blokland 2009) kokkuvõte ja edasiarendus, siis morfosüntaksi käsitlus keskendub ainult varem uurimata nähtustele, kuid sedavõrd pealiskaudsemalt. Sõnavara puhul on võimalik teha kõrvutavaid tähelepanekuid ka vene mõju kohta ühiskeeles ja murretes, samas kui vene mõjust murrete morfosüntaksis on alusuuringute puudumise tõttu hetkel võimatu rääkida. 


\section{Vene keele mõju eesti keele sõnavaras}

Esimesed konkreetsed teated eesti-vene kontaktidest leksika vallas pärinevad ligi 300 aasta tagusest ajast: oma 1732. aastal ilmunud grammatikas ja sõnaraamatus lisab Anton Thor Helle lühikese vene laensõnade nimekirja; seitset tema pakutud sõna (aken, jaam, kapsas, raamat, saan, saabas ja ting) peetakse ka tänapäeval vene laenudeks. Varasemaid märkusi eesti-slaavi keelekontaktidest on siiski olemas, näiteks filosoof Gottfried Wilhelm Leibniz kirjutab 1693. aastal orientalist Hiob Ludolfile, et ta uurib eesti keele ja slaavi keelte suhteid (Wessel 2003/ 2004: 79), mainimata aga konkreetseid laene.

Esimene artikkel, mis on pühendatud tervenisti vene laensõnadele eesti keeles, pärineb 19. saj algusest (Brömsen 1814). Brömseni lähenemine on aga amatöörlik: seda näitab tema nimekiri, milles on eesti sõnu, millel on vene keeles sarnase häälikkoosseisu, kuid täiesti erineva tähendusega vasted. 1832. aastal avaldas Hupel lühikese artikli laensõnadest eesti keeles, milles ta mainib 37 oletatavat vene laensõna - neist 17 on aktsepteeritud ka tänapäeval. Järgmise vene laensõnadele pühendatud artikli ilmumiseks kulus enam kui sada aastat; see oli Villem Ernitsa uurimus „Russko-èstonskie jazykovye otnošenija“ (Èrnits 1947). Arusaadavatel põhjustel pälvisid vene-eesti keelekontaktid nõukogude ajal suuremat tähelepanu kui kunagi varem. Mari Must kaitses juba 1954. aastal vene laensõnadele eesti murretes pühendatud väitekirja, mis nägi ilmavalgust (laiendatud kujul) alles 2000. aastal. Must uuris laensõnu, mis tulid eesti murretesse alates 17. sajandist. Varasemast ajast pärit laensõnu on käsitlenud oma sugulaskeeli puudutavates töödes Mikkola (vt nt 1894), Kalima (1952) ja Mägiste (1962). Selliseid varasemaid laensõnu laenati idaslaavi kujust, mida nimetatakse kokkuleppeliselt 'vanavene keeleks' ja milles teatud häälikumuutused ei olnud veel toimunud. Kuulus näide on sundima, mida laenates asendati vanavene verbis suditi nasaalne vokaal vokaali ja nasaalse konsonandiga. Juhtumisi on seesama verb tulnud eesti murretesse ka hilisemast vene keele kujust, mis enam nasaali ei sisaldanud (vrd sudima 'hukka mõistma, hurjutama, laitma, süüdistama; keelt peksma, taga rääkima'; vt Must 2000: 383-384). Enamik sõnu, 
milles on nasaalse vokaali asendus, esineb ka teistes läänemeresoome keeltes, kuid und (vrd vanavene *uda; uusvene yda) esineb ainult eesti ja liivi keeles ning rent ('Reihe' Wiedemann 1893; vrd vanavene rędъ; uusvene (EEW VIII: 2458), kuigi selle päritolu kohta on ka alternatiivseletusi (Blokland 2009: 235-236). Vanemaid laensõnu laenati murretesse ja hiljem fikseeris kirjakeel need ühiskasutusse. Häälikkuju aga reedab kohati murret, mis on toiminud sillana vene keele ja eesti kirjakeele vahel; nt lahits, mis on laenatud vene sõnast лácuu̧a, näitab lõunaeestilist muutust $s>h$ (vrd Ahven 1958: 58).

Vene keele sõnavaraline mõju on kirjakeeles ja murretes üsna erineva tugevusastmega. Kõige tugevam on see Ida-Eestis, eriti Setu alal, kus mõju esineb ka foneemilises süsteemis (vrd Must 2000: 589-591). Võib kindlalt väita, et mõned eesti murded positsioneeruvad Thomasoni ja Kaufmani (1988: 75-76) kontakti intensiivsust näitaval laenuskaalal kõrgemal kui ühiskeel, mis ise asub kuskil teise ja kolmanda intensiivsusastme vahel (vt Blokland 2009: 357-360). Huvitav on näiteks nik-sufiksi juhtum, mis esindab Thomasoni ja Kaufmani skaala kolmandat intensiivsusastet, kus tuletussufikseid abstraheeritakse laensõnadest ja hakatakse kasutama oma tüvedega. Kuigi see sufiks on kindlasti vene päritoluga, ei esine ta väga vanades laensõnades (vanim dokumenteeritud sõna on koddenick (VTS: 94)). Seetõttu pakkus Mägiste (1968: 12), et antud sufiks on poollaenulise ja pooltõlkelaenulise päritoluga; vastav areng oleks vn огородник > ee aednik. Ühtlasi on Kiparsky (1965: 431), viidates 16. saj. isikunimedele, nagu Jan Wabbenick, Hans Wabbenicks szone, ahn Jurgen, des wabbenicken poysz, arvanud, et need ei ole eesti keele enda tuletised ( $v a b a+-n i k)$, vaid laenud vanavene sõnast svobodbnikb, mis on ilmselt olnud ka selle sufiksi algallikaks. Tänapäeva eesti kirjakeeles on see sufiks kaotamas oma produktiivsust (EKG I: 521), Lõuna-Eestis tundub aga olevat produktiivsem, sest seal tuletatakse sellega ka omadussõnu (nt halõdnik 'hale', hapnik 'hapu', EMS I: 314, 385). Muid morfoloogilisi laene vene keelest esineb natuke arhailisemas eesti ühiskeeles alates 1920. või 1930. aastatest; vrd nt -ной sõnades kehvnoi, vahvnoi, -ушка sõnas plikuska ja -ка sõnas täika (vt Blokland 
2009: 41-43). Näide nõukogude terminoloogiast on prefiks kom(vrd nt komnoor) ja vangide slängist pol- (vrd polvang, vn политзаключённьй). Võrdlemisi uus on prefiksoid euro-, mis on kahetist päritolu: sõnas eurointegratsioon on ta lääne päritolu, sõnas euroremont on aga tõenäoliselt laenatud vene mõistest евроремонт. ${ }^{2}$

Kirjakeele ja murrete laensõnade sõnaliigi võrdlus näitab, et umbes $92 \%$ vene laensõnadest eesti kirjakeeles on nimisõnad ja 5\% tegusõnad (Blokland 2009: 357-359), samas kui murretes on nimisõnade osakaal ainult $80 \%$ ja verbide oma 9,7\% (Must 2000: 581). Nimisõnade kõrge osakaal on ootuspärane, võttes arvesse nimisõna ainulaadse referendi staatust. Verbid on üldjuhul nimisõnadest morfoloogiliselt komplekssemad ning nende mugandamine eesti keelde on kulgenud erinevaid teid pidi. Verbid on üldiselt laenatud kas infinitiivist või finiitsest vormist, enamasti oleviku ainsuse esimesest või kolmandast isikust (nt kladima tuleb kas vormist кладу või кладёm, mitte aga infinitiivist класть). On olemas ka laene imperatiivi vormist, mis on üldiselt mugandatud eesti verbimorfoloogiaga (nt joputama < ёб; vrd ёб твою мать), kuid esineb ka otsest sissetoomist ilma mugandamiseta (nt jebitvoju 'sõimusõna', Must 2000: 56-57). Sarnane näide on pastoi (< nocmoŭ) (Baxman 1956: 8 ja Must 2000: 247), mis on hüüdsõna, ja padavai (< подавай) (Must 2000: 232), mis on määrsõna. Väljend taibaru tegema 'liiga tegema; valu andma; tõrelema, riidlema; minema ajama; karistama, peksma' (Must 200: 398), milles esimese elemendi taga olev vene daŭ napy moodustab väljendverbi eesti verbiga tege$m a$, on näide sõnamoodustusstrateegiast, mis on väga levinud idapoolsemates uurali keeltes. Ebaharilik on ka pogadii lauses VNg ärä veel mene, pogadii minu ka (Must 2000: 233), mida Must peab hüüdsõnaks (vrd Se mis ta nu ol'l, pagadi), kuid mis

\footnotetext{
${ }^{2}$ Vene päritolule viitab asjaolu, et mõiste 'euroremont' esineb ainult endise Nõukogude Liidu alal (vrd läti eiroremonts, leedu euroremontas ja ukraina євроремонт), mitte aga ülejäänud Ida-Euroopas, mis ei kuulunud Nõukogude Liitu. Samas esinevad läänest pärit europrefiksoidiga moodustised (nt euroskeptik, eurolaul, euroliiga) igal pool Ida-Euroopas (vt ka Szilárd Tóth, käsikiri).
} 
on sihitise minu tõttu analüüsitav antud lauses pigem imperatiivina.

Murded on laenanud rohkem omadussõnu $(4,1 \%$ kõikidest laenudest; Must 2000: 581) kui kirjakeel (1,9\% kõikidest laenudest; Blokland 2009: 358). Nagu eelnevast selgus, on vene keele omadussõnasufikseid abstraheeritud ja kasutatud eesti oma (enamasti slängi-) sõnavaras, kuid esineb ka selliseid näiteid, nagu järgnev näide Lutsi keelesaarelt, kus vene superlatiivne prefiks on kandunud eesti keelde; vrd preeillos 'väga ilus', mille preetuleb vene nре-st ja mis on moodustatud vene прекрасный eeskujul (Ariste 1965: 24).

Grammatilise funktsiooniga sõnad jagunevad oma laenutundlikkuse poolest kaheks rühmaks: esiteks on diskursusemarkerid ja sidesõnad, mida laenatakse kergelt (nt vot; murd. $a^{3}$ 'aga', hot' 'ehkki', -nibut liitasesõnas kuna nibut 'kunagi'; Must 2000: 549 ja Keevallik 2008); vrd ka vene keele emfaatilist partiklit $-m o$, mis on laenatud kirderannikumurde lisaku murrakusse (küll `este mina olin `kärme `marju-ta `korjama; Must 2000: 394); teiseks on arvsõnad ja asesõnad, mida üldiselt ei ole laenatud (sam naljaütluses sam saks olema 'selbst herr sein' (Wiedemann 1893) on vaevalt kunagi olnud kasutusel enesekohase asesõnana).

Nõukogude ajal on eesti kõnekeeles esinenud võrdlemisi palju vene laene, enamikul aga ei lastud eesti kirjakeelde juurduda; see on olnud eesti leksikograafide, kellest enamik olid Tartu Ülikooli lõpetanud eesti filoloogid, teadlik otsus ${ }^{4}$. Sellised laenud on näiteks bardakk, fartsama, hruštšovka, jeeli-jeeli, pohhuist, tavai (vrd Raag 1999: 218, Laanekask ja Erelt 2003: 329 ning Blokland 2009: 60). Samas on olemas juhte, kus eesti vastele eelistati pigem vene laenu, kui taheti näidata, et antud mõiste puhul on tegemist venelaste endi asjaga; nt perestroika uutmise asemel ja glasnost avalikustamise asemel (Laanekask ja Erelt 2003: 329). Slängisõnavaras on täheldatav vene mõju taganemine inglise mõju ees, kuigi kõrge kasutussagedusega ning

\footnotetext{
${ }^{3}$ Eesti kõnekeeles on vorm $a$ sõna $a g a$ rõhutum teisend, kagueesti murretes on ta aga pigem vene laen.

${ }^{4}$ Lembit Vaba, isiklik info.
} 
omaksvõetud sõnad, nagu pohhui ilmselt jäävadki esinema kõrvuti selliste inglise laenudega nagu kamoon.

\section{Vene keele mõju eesti keele morfosüntaksis}

Selles peatükis keskendume ühele eesti keeleteaduses 1990. aastatel vaidlusi tekitanud teemale - vene keele mõjule eesti keele grammatikas. Nende vaidluste aluseks on olnud üks ja sama küsimus: kas teatud keelemuutuse taga on vene keele grammatilised mallid või eesti keele sisemine areng? Vastavate kirjutiste loetelu on pikk, kuid selle verstapostideks võib pidada Hindi (1970, 1987, 1990, 1991, 1996 ja 1996a; vt ka Hindi seisukohtade koguteost: Hint 2002), Ehala (1994, 2000 ja 2009), Erelti ja Metslangi (1998), Hasselblatti (2000, 2000a) ja Tommola (2010) kirjutisi. Üldjuhul on iga pakutud seletus, mis omistab vene mõjule otsustavat rolli teatud keelemuutuses, tekitanud vastureaktsiooni ning soovi seletada sedasama muutust keele autonoomse arenguna. Need sisemise arengu seletused on olnud kõik veenvad: Mäger (1991) on näiteks seadnud kahtluse alla Mati Hindi väiteid vene mõjust eesti refleksiivverbide süsteemis, Ehala (1994) ei ole olnud nõus Hindi pakutud vene mõjuga eesti adpositsioonisüsteemis, ning Erelt ja Metslang (1998) on esitanud alternatiivseletusi praktiliselt kõikidele Hindi esitatud nähtustele: kvantoritarinditele ja ühildumisele, määruslikele täienditele, eituse paigutamisele, kaassõnadele, üldküsilausele, ühendverbidele ja aspektile, liitsete minevikuaegadele ja saama-tulevikule.

Enamik uurijaid, kes seletab „vene mõjusid“ keelesiseste arengutena, on arvestanud ka võimalusega, et vene keel on siiski võinud toimida võimendajana muutuste levimisel. Kogu poleemikale tagasi vaadates tekib aga küsimus, miks on morfosüntaksi puhul võõrkeele mõju nii raskesti tõestatav. Ei leidnud ju ükski kirjanduses pakutud vene mõju järgnevate uurijate heakskiitu. Miks on olukord morfosüntaksis niivõrd erinev sõnavaras valitsevast olukorrast, kus on liigutud palju kiiremini ja ühisjõul etümoloogilise tõe suunas (vrd Must 2000 ja Blokland 2009)? Põhjused ei ole niivõrd ideoloogilised, nagu esmapilgul paista võib (võõrmõju oma keele põhistruktuuris võib olla raske akt- 
septeerida), kuivõrd ontoloogilised. Grammatika teatavasti koosneb üldistunud (abstraktsetest) konstruktsioonidest; seetõttu avaldub võõrmõju siin pigem vormiainese kohandumisena võõraste struktuurimallidega kui otsese laenamisena. On teada näiteks, et aja ja aspekti markereid laenatakse ühest keelest teise harva, seevastu olemasolevate aja/aspekti vormistusmallide ümberstruktureerimist võõrkeele mõjul esineb tihti (Matras ja Sakel 2007: 844). Keele struktuurimallide (nt sõnajärje) kohandamine kontaktkeele mallidega aga peab alati olema kooskõlas selle enda struktuurilise eripära ja arengutrendidega. Kohandunud struktuur ei ole tavaliselt kontaktkeele omaga identne, sest viimases on omadusi, mille suhtes ei suudeta kompromissi saavutada (vt Matras ja Sakel 2007). Uus struktuur on justkui kahe laenuvõtja keele ja laenuandja keele - struktuuri hübriidvorm. Lisaks sellele toimub laenuvõtjas keeles ka sisearenguid, mis ei puuduta mitte üksnes uuendust läbivat struktuuri, vaid ka naaberstruktuure, mis teevad viimasele ruumi või vastupidi takistavad selle levikut. Helle Metslang (1996: 88-89) on toonud välja grammatikauuenduste juurdumist mõjutavate faktoritena 1) keelelise lähtematerjali olemasolu, 2) struktuurisobivuse, 3) kasutuspotentsiaali ja 4) tendentsisobivuse. Võimsaks struktuuri siseülekande mehhanismiks on ka analoogia. Seega tuleb grammatika puhul arvestada alati ka sisemiste teguritega, mis ühtlasi tähendab seda, et kui sõnavara puhul saame küsida „kas oma või võõras", siis grammatika puhul saame küsida ainult, kas teatud keelemuutuse põhjused on „,välised ja sisemised või ainult sisemised“. Võõrmõju eraldi käsitlemine ei olegi võimalik: seda saab uurida vaid keelemuutuse integreeritud vaatluse raames, mis on aga ekspertiisi ja aega nõudev töö.

Käeolevas peatükis pakume mõningaid vene mõju kandidaate, teisisõnu nähtusi, mille tekke ja leviku põhjused on ilmselt nii välised kui ka sisemised. Ükski neist ei ole leidnud kajastust varasemas eesti-vene kontakte puudutavas kirjanduses.

1. Eesti keeles võib loendamisel sõna kes esineda asesõna mõni või arvsõnade $\ddot{u k s, ~ t e i n e, ~ k o l m a s ~ j n e ~ a s e m e l, ~ n t ~ N u ̈ u ̈ d ~ o n ~}$ lapsed linnas. Kes läks tehasesse tööle, kes mehele, kes õpib instituudis (VNN: 263). Vrd Mõni läks tehasesse tööle, mõni mehele, mõni õpib instituudis. / Üks läks tehasesse tööle, teine me- 
hele, kolmas õpib instituudis. Nendes loendites toimib kes umbmäärasuse markerina, selekteerides piiratud isikute hulgast varasemast jutust tundmatu referendi. Tavaliselt on kes osalause subjekt, kuid registreeritud on ka üksikuid kasutusi objektina, nt .. viin ja ôlu oleksid nagu läbi purenud pidurdavad lukud ning riivid, viies kelle pisarateni, kelle uhkeldava praalimiseni, kelle sõjaka riiakuseni (EKSS). Taoline kasutus võib olla tekkinud vene keele eeskujul, kuna vene keel (erinevalt nt soome ja saksa keelest) kasutab taolistes loendites küsisõna кmo 'kes', vrd Teперь все дети в городе. Кто пошёл работать на завод, кто вышел замуж, кто учится в институте.

2. Eesti verbidel tasuma ja maksma on üks omapärane kasutus: vrd Ukse tagant paistis ere kollane valgus, kuid tasus mul koputada millisele tahes uksele, kui valgus kustus silmapilkselt (VNN: 125). Kuid maksis näha vaid profiilis ta nina ja energilist lõuga, et veenduda ta isekas tahtekindluses (EKSS). Antud konstruktsioonis esinevad tavaliselt verbid tarvitsema ja pruukima: vrd Tasus (= tarvitses, pruukis) võõral vaid aiale läheneda, kui koer endast märku andis (EKSS). Kuigi tundub, et tegemist on ajalausetega, mida saab sõnastada ümber, kasutades ajaväljendit: Niipea kui võõras aiale lähenes, andis koer endast mär$k u$; tundub, et need laused väljendavad ka tagajärge või isegi otstarvet: nt Maksab üks asi ära keelata, kui ta otsemaid ihaldusväärseks muutub (EKSS) = ,selleks et asi ihaldusväärseks muutuks, tasub see ära keelata“. Vahetegemine ühelt poolt aja- ja teiselt tagajärje-/otstarbelause vahel sõltub ilmselt ka põimlause ajast: lihtminevik vormistab ajalauset, olevik aga tagajärje-/otstarbelauset (vrd veel olevikus tagajärjelauset: Tasub ainult korraks seisatada, kui sääseparv ründab (EKSS) = „Mille tagajärjel sääseparv ründab?“). Nende verbide soome ja saksa vastetel (vrd sm kannattaa, sks lohnen) ei ole sellist kasutust, seevastu on kokkulangevus vene keelega üksühene. Verb cmoumb 'maksma, tasuma' esineb samas funktsioonis ja samasuguses pöördsõnajärjega tarindis, millele järgneb kui-lause; vrd Cтоит мне сказать, кем я работаю, как у собеседников тут же загораются глаза 'Tasub mul öelda, kellena ma töötan, kui kaaslastel lähevad kohe silmad põlema'. Nii nagu eesti keeles, on vene keeleski olevikulised laused tõlgendatavad pigem tagajärje- või 
otstarbelausetena, vrd $У$ меня очень сильно потеют ладони, стоит мне только чуть-чуть поволноваться или понервничать - ладони превращаются в сплошную воду 'Mu kämblad higistavad väga kõvasti, tasub mul vaid natuke erutuda või närvi minna, kui nad lähevad täitsa märjaks' (mille tagajärel?), minevikulised laused aga pigem ajalausetena: vrd Стоило мне только выпить бутылку алкоголя и сожрать батон хлеба с чесноком, как мне позвонили насчет работы 'Tasus mul ainult pudel alkoholi ära juua ja üks küüslaugubatoon ära süüa, kui mulle helistati töö asjus' ( = 'niipea kui jõin pudeli ära ..').

3. Eesti keeles võib kasutada sõna kõik perfektiivses tähenduses; vrd Need pühitakse niiske lapiga ja ongi kõik (VNN: 175). Eesti keele seletav sõnaraamat (EKSS) ütleb, et kõik esineb lause lõpul kokkuvõtva või rõhutava sõnana: Mis nad teha saavad, ma ei lähe - ja kõik!, Kuidas - miks? Tahan ja kõik. Selline kasutus peegeldab vene väljendit $u$ всё (vrd Hе nойду $u$ всё! 'Ma ei lähe ja kõik!' Хочy и всё! 'Tahan ja kõik!'), seda eriti koopulaverbi puudumise osas ( $j a$ Ø kõik).

4. Eesti keeles väljendab pöördsõnajärg arvsõnafraasis arvu umbkaudsust (numeerilist aproksimatiivi): sinna oli veel kilomeetrit viis 'umbes viis kilomeetrit', ta ootas minutit kümme 'umbes kümme minutit', Palju neid seal vankris on? «Tükki kuuskümmend või nii.» 'umbes kuuskümmend tükki' (VNN: 375). Numeerilise aproksimatiivi väljendamine sõnajärje pööramisega on tüpoloogiliselt äärmiselt haruldane. Konstanzi ülikooli grammatiliste harulduste kabinetis (http://typo.unikonstanz.de/rara/nav/browse.php) on see umbkaudse arvu väljendamise strateegia (nr 78) liigitatud kui rarissimum (kõige haruldasem). Ainsate keeltena, kus see esineb, on toodud idaslaavi keeled. On ülimalt tõenäoline, et eesti keeles on see konstruktsioon tekkinud vene keele eeskujul. Esiteks on vene keeles pöördsõnajärjega aproksimatiiv üsna tavaline konstruktsioon, nt собралось человек двадиать 'kogunes inimest kakskümmend', eesti keeles on see siiski marginaalne ja kõlab arhailiselt, ning soome keeles ei esine seda üldse. Teiseks on vähe tõenäoline, et konstruktsioon, mis esineb ainult ühes maailma piirkonnas, oleks tekkinud piirkonna keeltes iseseisvalt. Kolmandaks on teada, et sama tarind on levinud vene keelest ka näiteks komi 
keelde (Bubrix 1949: 95); vrd сэтчӧдз вӧли нӧшта вит километр 'sinna oli veel viis kilomeetrit' ja сэтчӧдз вӧли нӧшта километр вит 'sinna oli veel kilomeetrit viis'.

5. Eesti keeles ühildub subjektina talitleva sidendiga kes algavate relatiivlausete öeldis arvus relatiivlause korrelaadiga pealauses (EKG II 312). Siiski võib tänapäeva eesti keeles kohata ka lauseid, kus sellist ühildumist ei ole ; nt SPA-Ilu pakett on täiesti uus pakett neile, kes tahab hellitada end kõige populaarsemate spa-hoolitsustega ühes paketis (vrd .. neile, kes tahavad hellitada end ..). Ühesonnaga paras alternatiiv neile, kes ta$\underline{\text { hab }}$ omanäolist mänguasja, kuid kes ei taha selle eest maksta sellises suurusjärgus raha (vrd .. neile, kes tahavad omanäolist mänguasja ..). Jelena Tšerednikova, kes on uurinud oma bakalaureusetöös ühildumisvigu venekeelsete üliõpilaste töödes, väidab, et üks venelaste tüüpvigu on arvuühildumise neutraliseerimine kõrvallauses; nt Aga juhtub tihti nii, et ülikoolis hakkavad õppima need, kes maksis. Ta peab seda emakeelest tulenevaks interferentsiks, sest vene keeles esineb pronoomen, mille nimetava vormis eristatakse arvu (sg который / pl которые), eesti keeles aga sellist ei ole (vrd sg kes / pl kes) ning seetõttu käsitavad venelased pronoomenit kes ainsuslikuna (Tšerednikova 2002: 45-46). Tõenäolisem siiski on analoogia vene ühildumatu pronoomeniga $\kappa m o$, mis kontrollib ainsuslikku öeldist, sõltumata korrelaadi arvust pealauses; vene keeles öeldakse все люди, кто хочет снять квартиру в Москве (otsetõlkes 'kõik inimesed, kes tahab üürida Moskvas korterit') ja mitte *все люди, кто хотят снять квартиру в Москве 'kõik inimesed, kes tahavad üürida Moskvas korterit'. Selleks, et relatiivlause öeldis oleks vene keeles mitmuses, tuleks kasutada ühilduvat pronoomenit который (все люди, которые хотят снять квартиру в Москве). Väärib tähelepanu ka asjaolu, et Tšerednikova räägib vigastest lausetest, milles kes lähtevormiks pealauses on subjekt. Eestlaste eespool esitatud internetilausetes (nt paras alternatiiv neile, kes tahab omanäolist mänguasja) on kes lähtevormiks aga saajat märkiv määrus. Sellised laused alluvad vene keeles samale ühildumisreeglile: для тех (людей), кто хочет vs. для тех (людей), которые хотят). Kui oletada kõrvallause öeldise ühildumatuse puhul vene mõju, tuleks järelikult küsida, miks see 
on eesti keeles võimalik ainult juhul, kui sõna kes korrelaat pealauses on adverbiaal ja mitte subjekt või objekt (vt *need, kes maksis ja *nägin neid, kes maksis).

Mati Erelt (vt Erelt 1996, 1999 ja 2000), kes on uurinud eesti keele isikuühildumise struktuuri ning selles toimuvaid muutusi, on täheldanud üleüldist langustendentsi: „Mitmes [..] tüübis on isikuühildumine ja sellega seostuv arvuühildumine kas päris kadunud või kahanemas“ (Erelt 2000: 185). Seega oleks siin vaadeldav juhtum veel üks näide arvuühildumise taandarengust. Huvitavam on aga Erelti (1999: 30) väide, et ühildumise kohustuslikkus väheneb suunas subjekt $>$ objekt $>$ adverbiaal. Ühildumise kahanemise tendents peaks siis puudutama esiteks adverbiaalist korrelaati ja hiljem nihkuma mööda täheldatud hierarhiat üles. Erelti näited selle hierarhia kohta puudutavad kõrvallause öeldise isikuühildumist pealause korrelaadiga. Adverbiaalist korrelaadi puhul esineb ühildumiseta malle: Mulle, kes on siin juba tükk aega istunud (vrd Mulle, kes ma olen siin juba tükk aega istunud); subjektist korrelaadi puhul on ühildumatus võimalik ainult minevikus (Mina, kes on elanud siin kogu oma elu), mitte aga olevikus (*Mina, kes elab siin ..) (Erelt 1996: 18).

Tulles tagasi arvuühildumise juurde, võime tõdeda, et vene keelest tulev ühildumatuse mall on tänaseks marginaalselt puudutanud ainult neid juhte, kus sõnale kes vastab pealauses adverbiaal. Objektilise ja subjektilise korrelaadi puhul on arvuühildumine ikkagi kohustuslik; vrd *Ma nägin neid, kes tahab korterit üürida. *Kõik need, kes tahab korterit üürida.

6. Vene keel on eesti ja soome keelest elliptilisem. Selle elliptilisusega puutub kõige paremini kokku, kuulates või lugedes tekste vene keelest kõvasti mõjutatud idapoolsetes läänemeresoome keeltes, mille struktuuriline sarnasus eesti ja soome keelega on muidu suur. Antud elliptilisus seisneb eelkõige predikaadi ja objekti ärajätmises. On usutav, et ulatuslikud kontaktid vene keelega 20. sajandil on mõnevõrra kasvatanud eesti keele elliptilisust. Ellipsit eesti keeles on üldse väga vähe uuritud: Duvallon ja Chalvin (2004) ning Lindström jt (2009) on uurinud subjekti ellipsit, Kehayov (2009) on aga uurinud olema-verbi ellipsit ja võimalikku vene mõju selles. Peaaegu uurimata on objekti ellipsi küsimus. Nagu ka muude argumentide puhul, on 
objekti ellips täenäoliselt motiveeritud isiku varjamise taotlusest (vt Lindström 2010), kuid tundub, et teatud puuduva objektiga mallid on tõlkelaenulised. Selline on näiteks objekti väljajätt obligatoorse laiendiga vägivallaverbi järel: nt Katsu sa mul iitsatada - tapan Ø ära! Nagu iitsatad - peksan Ø läbi! Vene keeles on vägivallaverbi objekti ellips väga sagedane nähtus (vrd Tолько пикни у меня - убью! Если пикнешь - поколочу! Пикнешь, изнасилую!), ning samas on vene keelest vähe mõjutatud soome keeles taoline ellips võimatu (vrd *Tapan! *Hakkaan!).

7. Eesti keeles saab kasutada imperatiivi ainsuse teise isiku vormi koos teiste isikutega käsu või kohustusega mittenõustumise puhul marginaalselt; nt Ise puhkab, aga mina (meie, nemad) tööta! Tänapäeva eesti keeles on sellised kasutused äärmiselt haruldased; nendes on tavaliselt käsu täitjaks kas eksplitsiitne või implitsiitne esimene isik; nt Tõesti, tegemist on palju. Inimesed mundkui paluvad minult igasugu asju! Ja mina muudkui kuula siis nende hädasid ja katsu aidata! (Eesti Päevaleht 02.06.2007: <http://maja.epl.ee/artikkel/388159>. Vaadatud 30.03.2010); Ikka sama ja sama - muudkui mõtle teiste eest! Ainus mida pakkuda saan, on loomalaut.(<http://www.eestilastemisjon.ee/pdf/Minu_elus.pdf $>$. Vaadatud 30.03.2010). Antud konstruktsioon, mida on nimetatud kajaimperatiiviks (Holvoet 2007: 118-121), on üks vene keele iseloomulikumaid jooni; vrd Он сам отдыххает, а я (мы, они) работай. Xrakovskij ja Volodin (1986: 237) on tõstnud esile vene kajaimperatiivi kahte põhiomadust: a) ta esineb tavaliselt liitlausetes, mille üks osalause väljendab soovitud olukorda, kus teised viibivad, teine aga kõneleja mittenõustumist tegevussubjektile peale sunnitud olukorra või kohustusega; b) sellised kajaimperatiivid on tavaliselt faktiivsed, mis tähendab, et neid kasutatakse siis, kus tegevussubjekt ikkagi täidab talle peale sunnitud kohustuse, olgugi et vastu oma tahtmist. Täpselt samu omadusi näeme ka eesti kajaimperatiivi puhul, nt Nemad on juba koju läinud, aga mina muиdkui korista! Irina Külmoja (Külmoja 1991: 153), kes on uurinud kõrvutavalt eesti ja vene imperatiivi sekundaarkasutusi, toob (muuhulgas) ära kaks ühiskasutust, mis kuuluvad Xrakovskij ja Volodini esimese punkti alla: a) väljendada kõrvallauses kohustust, sundust: $B$ вы все ломаете, а я (мы, они) 
чини 'teie rikute kõike, aga mina - toimeta'. Külmoja näide sellise kasutuse kohta eesti keeles pärineb Ernst Peterson-Särgava loomingust: Poiss ajab häbematusi suust välja, papa kuuleb pealt ja mina saa tapelda; b) väljendada seda, et verbiga väljendatud tegevus on kõneleja jaoks vastuvõetamatu: Она мне велит не беспокоиться. Как это я не беспокойся, когда .. 'Ta käsib mul mitte muretseda. Kuidas nii, mitte muretseda, kui ..'; eesti näide selle kasutuse kohta on Külmoja arvates Lonni, Lonni taltsuta end natuke, ise noor inimene! Mina taltsuta end .. mina taltsuta, kui sina mammale liiga teed. (PetersonSärgava)

Kuna struktuuriline ja funktsionaalne kokkulangevus on niivõrd suur, võime oletada, et vene keel on siin olnud eesti keelele eeskujuks. Selle hüpoteesi kasuks räägib ka distributiivne kokkulangevus. Vene keeles saab ainsuse teise isiku imperatiivi kombineerida mistahes isikuga ja ka isikunimega; sama on põhimõtteliselt võimalik ka eesti keeles, olgugi et väga marginaalselt, nt Teised puhkavad, aga meie muudkui tööta! Teised puhkavad, aga nemad muudkui tööta! Kõik puhkavad, aga Peeter muudkui tööta. ${ }^{5}$ Lisaks sellele ei tundu eesti keeles täiesti võimatuna ka eitava imperatiivi vormi kombineerimine teiste isikutega; vrd Как это я не беспокойся!, 'Kuidas mina ära muretse! Vene keeles on see konstruktsioon aga palju suurema kasutussagedusega, mis on ka ootuspärane, sest see pidi eesti keeles konkureerima palju sagedasema jussiiviga.

\section{Lõpetuseks}

Vene keele mõju on uuritud eesti keele erinevatel tasanditel väga ebaühtlaselt. Kui sõnavara kohta on hetkel olemas juba kaks ammendavat monograafiat (vt Must 2000 ja Blokland 2009), siis morfosüntaksi puhul saame süstemaatilistest vene mõjule pühen-

\footnotetext{
${ }^{5}$ Tuleb tunnistada, et mõned emakeelsed kõnelejad annavad üsnagi erinevaid hinnanguid nende konstrueeritud lausete grammatilisusele. Paljude jaoks on sellised kajaimperatiivid vastuvõetavad ainult koos esimese isikuga.
} 
datud uurimustest praegu ainult unistada. Enam-vähem samasugune olukord valitseb aga ka saksa ja läti morfosüntaksi mõju uurituse osas, mis jällegi näitab seda, et morfosüntaksi „mahajäämuse" põhjused ei ole niivõrd ideoloogilised, kuivõrd ontoloogilised.

Käesolev uurimus esitas mitu uut vene mõju kandidaati. Oma üldises hinnangus vene-eesti keelekontakti intensiivsusele aga jääme siiski Bloklandi (2009: 357-360) seisukoha juurde, et vene keele mõju eesti keelele positsioneerub oma ulatuselt Thomasoni ja Kaufmani (1988) skaalal allapoole kolmandat astet. Kui täpsem olla, siis võiksime eesti kirjakeele paigutada pigem teisele astmele, eesti idapoolsemad murded, kus on mõningaid kolmanda astme tunnuseid, aga kolmandale astmele lähemale, ja kõnekeele nende kahe vahele.

Jääme lootma, et tulevikus jätkub keeleuurijaid, kes tunnevad huvi vene mõju vastu eesti keeles. Eesti venelaste eesti keele oskus kasvab vähemalt samas tempos, milles väheneb pealetulevate eesti põlvkondade vene keele oskus. Seega ei maksa väga muretseda, et eestlastest uurijate vähene keeleoskus seaks siin lati liiga madalale. Eesti-vene (mõlemasuunaliste) kontaktide uurimine on tagatud seni, kuni suudetakse tagada Eesti venelastest uurijapõlvkonna juurdekasv.

Rogier Blokland

Institut für Finnougristik/Uralistik

Universität Hamburg

Johnsallee 35, 20148 Hamburg

Saksamaa

Rogier.Blokland@uni-hamburg.de

Petar Kehayov

Eesti ja üldkeeleteaduse instituut

Tartu Ülikool

Ülikooli 18-138, 50090 Tartu

Petar.Kehayov@ut.ee 


\section{Kirjandus}

Aavik, Johannes (1936) Eesti õigekeelsuse õpik ja grammatika. Tartu: Noor-Eesti Kirjastus.

Ahven, Eeva (1958) Eesti kirjakeele arenemine aastail 1900-1917. (Keele ja Kirjanduse Instituudi Uurimised IV.) Tallinn: Eesti Riiklik Kirjastus.

Ariste, Paul (1965) "A case of language contact in the East Baltic area”. Sovetskoe finno-ugrovedenie I, 1, 21-25.

Baxman, Karl I. (1956) Issledovanie russkix leksičeskix zaimstvovanij $v$ èstonskom jazyke (po materialam publicistiki i leksikografii vtoroj poloviny XIX $i$ načala $X X v v$ ). Avtoreferat dissertacii na soiskanie učenoj stepeni kandidata filologičeskix nauk. Leningrad.

Blokland, Rogier (2009) The russian loanwords in literary Estonian. (Veröffentlichungen der Societas Uralo-Altaica 78.) Wiesbaden: Harrassowitz.

Brömsen, Karl Moritz von (1814) "Sammlung von Wörtern, welche aus der russischen Sprache in die ehstnische gekommen sind". Beiträge zur genauern Kenntnisz der Ehstnischen Sprache 3, 139149.

Bubrix, Dimitrij Vladimirovič (1949) Grammatika literaturnogo komi jazyka. Leningrad: Izdatel'stvo Leningradskogo Gosudarstvennogo Ordena Lenina Universiteta Imeni A. A. Ždanova.

Duvallon, Outi, Antoine Chalvin (2004) "La réalisation zéro du pronom sujet de première et de deuxième personne du singulier en finnois et en estonien parlés". Linguistica Uralica XL, 4, 270-286.

EEW = Mägiste, Julius (1982-1983) Estnisches etymologisches Wörterbuch I-XII. Helsinki: Finnisch-Ugrische Gesellschaft.

Ehala, Martin (1994) "Russian influence and the change in progress in the Estonian adpositional system". Linguistica Uralica XXX, 3, 177-193.

Ehala, Martin (2000) "Second language learner's impact on the structure of Estonian". Kiira Allikmets, toim. Languages at universities today and tomorrow, 20-32. Tartu: Tartu University Press.

Ehala, Martin (2009) „Keelekontakti mõju eesti sihitiskäänete kasutamisele“. Keel ja Kirjandus 52, 3, 182-204.

EKG I = Erelt, Mati, Reet Kasik, Helle Metslang, Henno Rajandi, Kristiina Ross, Henn Saari, Kaja Tael, Silvi Vare Eesti keele grammatika I. Morfoloogia. Sõnamoodustus. Trükki toimetanud Mati Erelt (peatoimetajana), Tiiu Erelt, Henn Saari, Ülle Viks. Tallinn: Eesti Teaduste Akadeemia Eesti Keele Instituut, 1995. 
EKG II = Erelt, Mati, Reet Kasik, Helle Metslang, Henno Rajandi, Kristiina Ross, Henn Saari, Kaja Tael, Silvi Vare. Eesti keele grammatika II. Süntaks. Lisa: kiri. Trükki toimetanud Mati Erelt (peatoimetajana), Tiiu Erelt, Henn Saari, Ülle Viks. Tallinn: Eesti Teaduste Akadeemia Keele ja Kirjanduse Instituut, 1993.

EMS I = Eesti murrete sõnaraamat I. Tallinn: Eesti Teaduste Akadeemia Eesti Keele Instituut, 1994-1997.

EKSS = Eesti keele seletav sõnaraamat. Tallinn: Eesti Keele Sihtasutus, 2009.

Erelt, Mati (1996) "Relative words in Estonian relative clauses". Mati Erelt, toim. Estonian: Typological Studies I, 9-23. (Publications of the department of Estonian of the University of Tartu 4.) Tartu.

Erelt, Mati, Helle Metslang (1998) „Oma või võõras?“ Keel ja Kirjandus 41, 10, 657-668.

Erelt, Mati (1999) “Agreement in Estonian”. Mati Erelt, toim. Estonian: Typological Studies III, 7-46. (Publications of the department of Estonian of the University of Tartu 11.) Tartu.

Erelt, Mati (2000) „Arvuühildumisest tänapäeva eesti kirjakeeles“. Keel ja Kirjandus 43, 3, 180-189.

Ernits = Èrnits, Villem (1947) „Russko-èstonskie jazykovye otnošenija”. Paul Ariste, toim. Filoloogilisi ettekandeid, peetud soome-ugri teaduste konverentsil Leningradis 1947. a, 115-131. (Tartu Riikliku Ülikooli Toimetised 4. Nõukogude soome-ugri teadused 3.) Tartu: RK "Teaduslik Kirjandus".

Hasselblatt, Cornelius (2000) "Estonian between German and Russian: facts and fiction about language interference". Dicky Gilbers et al., toim. Languages in Contact, 134-144. (Studies in Slavic and General Linguistics 28.) Amsterdam/Atlanta, GA.

Hasselblatt, Cornelius (2000a) "The Finnic verb pattern: clues to (morpho)syntactic change?” Johanna Laakso, toim. Facing Finnic. Some challenges to historical and contact linguistics, 64-79. (Papers from a symposium held in Tartu, Estonia, August 8th, 2000. Castrenianumin toimitteita 59).

Hint, Mati (1970) „Eesti keelekorraldus - kust, kuhu ja milleks? Mõtteid viimaste aastakümnete tendentsidest ja tulevikuperspektiividest“. Looming 8, 1237-1245.

Hint, Mati (1987) „Vaateid kakskeelsusele roosade prillideta“. Vikerkaar 6, 51-56; 7, 46-50.

Hint, Mati (1990) „Vene keele mõjud eesti keelele“. Akadeemia 2, 1383-1404. 
Hint, Mati (1991) "The changing language situation: Russian influences in contemporary Estonian". Journal of Multilingual and Multicultural Development 12, 1-2, 111-116.

Hint, Mati (1996) „Indo-euroopa mallide lisandumine eesti keele analüütilises morfoloogias“. Congressus Octavus Internationalis Fenno-Ugristarum Jyväskylä 10.-15. 8. 1995. Pars IV, 183-185. Jyväskylä: Moderatores.

Hint, Mati (1996a) „Eesti keel okupatsiooni järel“. Keel ja Kirjandus $39,12,802-808$.

Hint, Mati (2002) Keel on tõde on õige ja vale. Tartu: Ilmamaa.

Holvoet, Axel (2007) Mood and Modality in Baltic. Kraków: Wydawnictwo Uniwersytetu Jagiellońskiego.

Hupel, August Wilhelm (1832) "Erklärung des Ursprungs jetzt ehstnischer Wörter aus fremden Sprachen. Ein Beitrag zu dem, im ersten Hefte S. 75 u. f. befindlichen, Aufsatze". Beiträge zur genauern Kenntnisz der Ehstnischen Sprache 20, 120-129.

Kalima, Jalo (1952) Slaavilaisperäinen sanastomme. Tutkimus itämerensuomalaisten kielten slaavilaisista lainasanoista. (Suomalaisen Kirjallisuuden Seuran Toimituksia 243.) Helsinki: Suomalaisen Kirjallisuuden Seura.

Keevallik, Leelo (2008) "Internal development and borrowing of pragmatic particles: Estonian vaata/vat 'look', nääd 'you see', and vot". Finnisch-Ugrische Mitteilungen 30/31, 23-54.

Kehayov, Petar (2009) „Olema-verbi ellipsist eesti kirjakeeles“. Emakeele Seltsi aastaraamat 54 (2008), 107-152. Tallinn: Teaduste Akadeemia Kirjastus.

Kiparsky, Valentin (1965) "Review of Mägiste 1962". Zeitschrift für slavische Philologie 32, 428-434.

Külmoja = Kjul'moja, Irina (1991) “O vneimperativnom upotreblenii form povelitel'nogo naklonenija v russkom i èstonskom jazykax". Slavjano-slavjanskie $i$ slavjano-finno-ugorskie sopostavlenija = Slovensko-slovenska i slovensko-ugrofinska poredenja, 149-157. (Slavica Tartuensia 3. Tartu Ülikooli toimetised 932.) Tartu.

Laanekask, Heli, Mati Erelt (2003) "Written Estonian". Mati Erelt, toim. Estonian language, 273-342. (Linguistica Uralica. Supplementary Series / vol 1.) Tallinn: Estonian Academy Publishers.

Lindström jt 2009 = Lindström, Liina, Mervi Kalmus, Anneliis Klaus, Liisi Bakhoff, Karl Pajusalu (2009) „Ainsuse 1. isikule viitamine eesti murretes“. Emakeele Seltsi aastaraamat 54 (2008), 159-185. Tallinn: Teaduste Akadeemia Kirjastus. 
Lindström, Liina (2010) „Kõnelejale ja kuulajale viitamise vältimise strateegiaid eesti keeles“. Emakeele Seltsi aastaraamat 55 (2009), 88-118.

Matras, Yaron, Jeanette Sakel (2007) "Investigating the mechanisms of pattern replication in language convergence". Studies in Language 31 (2007), 829-865.

Metslang, Helle (1996) „Evolutsioonilised ja revolutsioonilised uuendused grammatikas“. Congressus Octavus Internationalis FennoUgristarum. Jyväskylä 10.-15. 8. 1995: Pars IV, 87-92. Jyväskylä: Moderatores.

Mikkola, Jooseppi Julius (1894) Berührungen zwischen den westfinnischen und slavischen Sprachen (Mémoires de la Société Finno-Ougrienne 8.) Helsingfors: Finnische Litteraturgesellschaft.

Must, Mari (2000) Vene laensõnad eesti murretes. Tallinn: Eesti Keele Sihtasutus.

Mäger, Mart (1991) „Refleksiivid - sajandi järjepidevus“. Keel ja Kirjandus 34, 6, 343-355.

Mägiste, Julius (1962) Äldre ryska lånord $i$ estniskan, särskilt $i$ det gamla estniska skriftspråket (Lunds Universitets Årsskrift N. F. Avd. 1, Bd. 55. Nr. 1). Lund: Gleerup.

Mägiste, Julius (1968) "Suffixentlehnung in den finnisch-ugrischen Sprachen, insbesonders aus dem Russischen”. Suomalais-ugrilaisen seuran aikakauskirja 69, 1-30.

Raag, Raimo (1999) Från allmogemål till nationalspråk. Språkvård och språkpolitik $i$ Estland från 1857 till 1999 (Acta Universitatis Upsaliensis. Studia Multiethnica Upsaliensia 12.) Uppsala: Uppsala University Library.

Zabrodskaja, Anastassia (2009) Russian-Estonian language contacts: grammatical aspects of language use and change. (Tallinn University Dissertations on Humanities.) Tallinn: Tallinn University.

Thomason, Sarah Grey, Terrence Kaufman (1988) Language contact, creolization, and genetic linguistics. Berkeley, Los Angeles and Oxford: University of California Press.

Thor Helle, Anton (1732) Kurtzgefaszte Anweisung Zur Ehstnischen Sprache. Halle: Stephan Orban.

Tommola, Hannu (2010) "Estnisch unter Einfluss. Entartete uralische Morphologie, deutsche Syntax und russische Semantik?" Tilman Berger, Markus Giger, Sibylle Kurt, Imke, Mendoza, toim. Von grammatischen Kategorien und sprachlichen Weltbildern - Die Slavia von der Sprachgeschichte bis zur Politsprache. Festschrift für Daniel Weiss zum 60. Geburtstag, 587-600. (Wiener Slawistischer Almanach, Sonderband 73.) München/Wien: Sagner. 
Tóth, Szilárd, Kõik euro-: ühe sõnamoodustuse vahendi semantikast, grammatikast ja etümoloogiast tänapäeva eesti keeles. Artikli käsikiri.

Tšerednikova, Jelena (2002) Ühildumisvead vene üliõpilaste kirjalikes töödes. Käsikirjaline bakalaureusetöö. Tartu: Tartu Ülikool. Eesti keele (võõrkeelena) osakond.

Verschik, Anna (2008) Emerging bilingual speech: from monolingualism to code-copying. London: Continuum publishers.

VNN = Vene nõukogude novell. Koostanud Naftoli Bassel, Valeri Bezzubov. Tallinn: Eesti Raamat, 1974.

VTS = Ehasalu, Epp, Külli Habicht, Valve-Liivi Kingisepp, Jaak Peebo (1997) Eesti keele vanimad tekstid ja sõnastik. (Tartu Ülikooli eesti keele õppetooli toimetised 6.) Tartu: Tartu Ülikool.

Wessel, Katri (2003/2004) "Leibniz und das Finno-Ugrische in seinem Briefwechsel (Teil I)". Ural-altaische Jahrbücher (Neue Folge) 18, 67-102.

Wiedemann, Ferdinand Johann (1893) Ehstnisch-deutsches Wörterbuch. Zweite vermehrte Auflage. Redigirt von Jacob Hurt. St. Petersburg: Eggers \& Co.

Xrakovskij, Viktor Samuilovič, Volodin, Aleksandr Pavlovič (1986) Semantika i tipologija imperativa. Russkij imperativ. Leningrad.

Rogier Blokland, Petar Kehayov: The Influence of Russian on Estonian: Hindsight and Outlooks. The present paper consists of two parts: a) the influence of Russian on Estonian lexicon, and b) the influence of Russian on Estonian morphosyntax. The first part is a summary of previous research, whilst the second part deals with a number of topics not explored previously. Estonian lexical loans can be roughly divided into pre-Soviet and post-Soviet loans. In dialects and colloquial Estonian Russian influence has been strong enough for a number of morphological elements to have been borrowed in addition to discourse markers and conjunctions. Russian origin is also suggested for a number of morphosyntactic features: the use of kes 'who' as a numerator; uses of the verbs tasuma and maksma in clauses embedding purpose or result clauses; perfective use of kõik 'all'; numeral approximativity expressed by word order inversion; incongruence in relative clauses, predicated and object ellipsis, and the use of the socalled echoic imperative.

Keywords: language contact, interference, Estonian, Russian, lexicon, morphosyntax 